\title{
Antioxidant Activity of Quercetin: A Mechanistic Review
}

\author{
Senay Ozgen ${ }^{1}$, Ozgur Kivilcim Kilinc ${ }^{1}$, Zeliha Selamoglu ${ }^{2 *}$ \\ ${ }^{I}$ Department of Plant Productions and Technologies, Faculty of Agricultural Sciences and Technologies, Omer Halisdemir University, \\ 51240 Niğde, Turkey \\ ${ }^{2}$ Department of Biotechnology, Faculty of Arts and Science, Omer Halisdemir University, 51240 Niğde, Turkey
}

\begin{tabular}{l}
\hline A R T I C L E I N F O \\
\hline Article history:
\end{tabular}

A B S T R A C T
Flavones and flavonoids are known to have potent antioxidant activity due to intracellular
free radical scavenging capacities. Flavonoids are found ubiquitously in plants as a
member of polyphenolic compounds which share diverse chemical structure and
properties. Quercetin is among the most efficient antioxidants of the flavonoids. The
antioxidant property of quercetin has been highlighted in this review. These compounds
have pivotal role in treatment of diabetes, cancers and some cardiovascular diseases.

Keywords:

Quercetin

Oxidative stress

Flavonoid

Antioxidant

Plant

${ }^{*}$ Corresponding Author:

E-mail: zselamoglu@ohu.edu.tr

Türk Tarım - Gıda Bilim ve Teknoloji Dergisi, 4(12): 1134-1138, 2016

\section{Kuersetinin Antioksidan Aktivitesi: Mekanik Bir Derleme}

\section{A K A L E B İ L G İ S İ}

Geliş 09 Kasım 2016

Kabul 29 Kasım 2016

Çevrimiçi baskı, ISSN: 2148-127X

Anahtar Kelimeler:

\section{Kuersetin}

Oksidatif stres

Flavonoidler

Antioksidanlar

Bitki

\section{Ö Z E T}

Flavonlar ve flavonoidlerin, hücre içi serbest radikal süpürme kapasitelerinden dolayı güçlü antioksidan aktiviteye sahip oldukları bilinmektedir. Flavonoidler, polifenolik bileşiklerin çeşitli kimyasal yapı ve özelliklerini paylaşan bir üyesi olarak bitkilerde bulunmaktadır. Quercetin, flavonoidlerin en etkili antioksidanları arasında yer almaktadır. $\mathrm{Bu}$ derlemede quercetin'in antioksidan özellikleri vurgulanmıştır. Bu bileşikler diyabet, kanser türleri ve bazı kardiyovasküler hastalıkların tedavisinde önemli rol oynamaktadırlar. 


\section{Introduction}

Flavonoids are found ubiquitously in plants as a member of polyphenolic molecules that share diverse chemical structure and properties. There are more than 4.000 various flavonoids have been characterized within the main flavonoid group which involve flavonols, flavones, flavanones, catechins, anthocyanidins, isoflavones, dihydroflavonols and chalcones (Cook et al., 1996). The food industry uses natural antioxidants to protect nutrients and color in the food. Recently, the numbers of the studies conducted for the use of flavonoids in different areas of industry are increasing. Similarly, possible use of these compounds is being common due to their antioxidant properties in the area of food, textile, leather, metallurgy, medicine and agriculture. Thus, quercetin is a common source for food and pharmaceutical industries. Quercetin (3, 5, 7, 3', 4'pentahydroxyflavone) is classified as a flavonol which is one of the five subclasses and major dietary flavonoids distributed in both cultivated and wild plants. (Cook et al., 1996; D'Andrea, 2015).

Many factors, for instance, development of technologies, the greenhouse effect, environmental pollution, smoking, radiation and many chemicals, cause negative effects of oxidative stress in the human body, as a result, stress-free radicals occur. It is proven that oxidative stress and free radicals provoke aging and disease in the body. Characterization of components capable of natural flavonoid antioxidants and their antioxidative effects have become increasing interest (Selamoglu et al., 2016). Antioxidants are organic compounds with non enzymatic low concentrations that prohibit the free radical oxidation mechanism (Das, 1989). Flavones and flavonoids, particularly quercetin, are known to reveal important cytotoxicity process against cultured human cells via raising intracellular reactive oxygen species amount (Yáñez et al., 2004). In this review, the effect of quercetin for the role of free radical scavenger will be presented.

\section{Chemistry of Quercetin}

A hydroxyl group in third carbon, a double bond between second and third carbon, a carbonyl group in fourth carbon and polyhydroxylated $\mathrm{A}$ and $\mathrm{B}$ aromatic rings (Figure 1) have main role in antioxidant proprieties of these compounds (Cook et al., 1996).

The first resonant structure where B ring has an orthocatechol group may enable the forming of intra- and intermolecular hydrogen bonds. Indeed, the flavones, include an ortho-catechol group (myricetin, quercetin, and luteolin) are more acidic than apigenin and kaempferol, in which the B-ring only have a 4' hydroxyl group. Luteolin and quercetin have two hydroxyl groups in the B-ring, on the contrary of myricetin. Thus, the more numbers of connected hydroxyl groups in the B-ring defines the acidity capacity.

The scavenging mechanism of the free radical by quercetin has been discussed on the rational of different AM1 and quantum mechanics calculation, the attained boundary orbitals and total spin intensity (Vasilescu and Girma, 2002). The analysis results of the spin density near by the attained free radical $4^{\prime}$-quercetin implies that the essential intensity of spin $\alpha(\uparrow)$ is condensed in the B ring on the O4' oxygen. They noticed also a light delocalization of spins $\alpha(\uparrow)$ and $\beta(\downarrow)$ on the B ring and on a part of the $\mathrm{C}$ ring. Authors concluded that quercetin antioxidant capacity may be related to basically with the $\mathrm{B}$ ring and a half of the $\mathrm{C}$ ring (Vasilescu and Girma, 2002).

The correlation of these flavonoids with $\mathrm{Cu}^{2+}$ ions was examined for their obscure composition of chelation or modification through oxidation, as well as in their structural relation (Brown et al., 1998). It has been implied that the ortho 3', 4'-dihydroxy substitution in the $\mathrm{B}$ ring is critical for a $\mathrm{Cu}^{2+}$-chelate formation which affects the antioxidant activity. Furthermore, it has been shown that the existence of a 3-hydroxy group in the flavonoid structure promotes the oxidation of quercetin and kaempferol. On the other hand, luteolin and rutin are absent in the 3-hydroxy group which they do not oxidize as easily in the existence of $\mathrm{Cu}^{2+}$ ions (Brown et al., 1998). In addition, it is observed that complexation of magnesium $\left(\mathrm{Mg}^{+2}\right)$ cation increases the free radical scavenging capacity of quercetin which inhibits oxidant damage and cell mortality via different pathways (Ghosh et al., 2015).

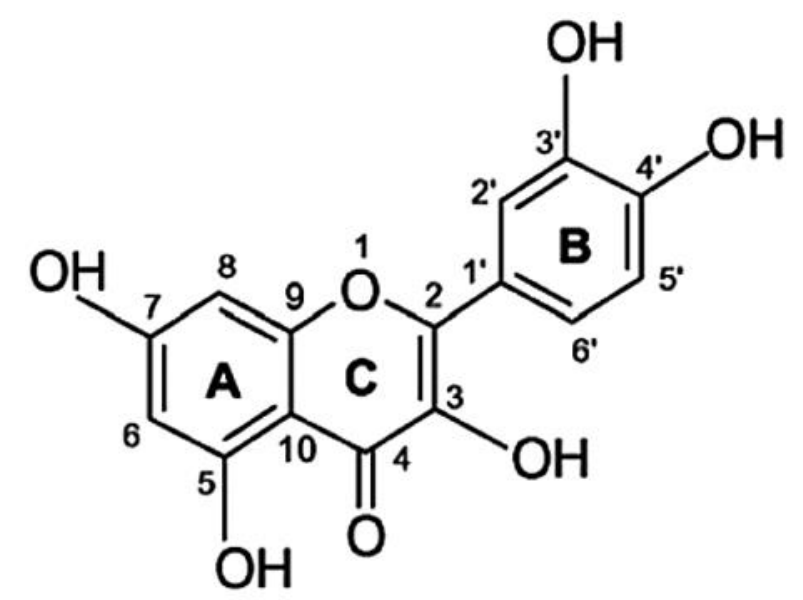

Figure 1 The structure of quercetin (Modified from Mitchell, 1965).

\section{Sources of Quercetin}

Quercetin is one of natural flavonoid group that is most common as a secondary metabolite in plants. Production of synthetic flavonoids has not been practiced yet. Hence, plants are the only sources for quercetin (Abdelmoaty et al., 2010). Major vegetables and fruits that are commonly consumed comprise different classes of flavonoids in varied amount. It has been found that onion has the highest amount of quercetin (about 300 $\mathrm{mg} / \mathrm{kg}$ ) among tested nutrition (Beecher, 1999). Other vegetables, such as broccoli and kale, included quercetin 
and kaempferol, but at much lower content. However, tea contains a high amount of catechins but low amounts of flavonoid quercetin (Beecher, 1999). The colour of fruits and vegetables indicates amount of flavonoids, as red grapes, cherries and blueberries have a significant amount of variant anthocyanins. Most of these fruits also contain flavonoids, especially quercetin (Beecher, 1999).

\section{Quercetin and Oxidative Stress}

The antioxidant character of quercetin is associated to chemical structure, especially the presence and location of the hydroxyl $(-\mathrm{OH})$ substitutions and the catechol-type Bring (Rice-Evans et al., 1996; Wang et al., 2006). The structural properties of a potent antioxidant capacity is due to the presence of (i) an ortho-dihydroxy or catechol group in the B-ring, (ii) a 2,3-double bond, and (iii) hydroxyl substitution at positions 3 and 5 (Bors et al., 1990). Growing evidence has demonstrated that quercetin, which is featured by a hydroxylation form of 3, 5, 7, 30, and 40 and a catechol B-ring, contains all the structural properties of an antioxidant agent (Silva et al., 2002; Rietjens et al., 2005). Quercetin has anticarcinogenic and anti-inflammatory properties with antioxidant and free radical scavenging effects. However, quercetin may also be diverted into reactive molecules (Metodiewa et al., 1999; Boots et al., 2003). In vitro, the oxidative degradation of quercetin has been showed to result in the formation of a free radical orthosemiquinone intermediate, which may afterward be changed to the parent molecule or to an orthoquinone, nearby the manufacturing of reactive oxygen species (Metodiewa et al., 1999; Boots et al., 2003). In conclusion, the possible pro-oxidant property of quercetin, especially at high dose levels, must be emphasized (Rietjens et al., 2005). As a result, the prooxidant effect may be accountable for the in vitro mutagenic action of quercetin. Also, the researchers reported that under aerobic conditions, quercetin was demonstrated to produce dose-dependent DNA damage and lipid peroxidation in isolated rat liver nuclei and oxygen radicals produced by autooxidation of the flavonol (Rahman et al., 1992; Sahu and Washington, 1991). Oxidative stress is related to reactive oxygen species which is the main factor for viral hepatitis, fibrosis, cirrhosis and liver cancer formation (Preedy et al., 2014). Recent studies show that some flavonoids prevent the occurrence of superoxide and hydroxyl radicals which cause lipid peroxidation.

Some researchers suggested that quercetin has antimicrobial, antiviral, antioxidative and antiinflammatory activities (Doğan et al., 2015; Gutteridge, 1995). Also, it is able to increase the cellular antioxidant potential via the Nrf2 pathway (Gutteridge, 1995). Another study by Doğan et al. (2015) has showed that quercetin is able to prevent against the toxic action of chemotherapeutic substances treated prior to pregnancy (Doğan et al., 2015). Quercetin was applied at a dose of $10 \mathrm{mg} / \mathrm{kg} /$ day by oral gavage. After $48 \mathrm{~h}$ of the experimental chemotherapy exposure, female rats were transferred to cages including male rat for mating.
According to this study, women who have been exposed to chemotherapy and may be pregnant should be treated with antioxidant molecules, such as quercetin to decrease the risk of injury to fetal brain tissues. In addition, the data of this investigation assessed the hypothesis that quercetin can prevent the toxic actions of chemotherapeutic compounds treated prior to pregnancy (Doğan et al., 2015).

Some experimental studies on animals are declared that the antioxidant effects of quercetin decrease oxidative injury to the tissues such as the brain, heart in ischemic reperfusion damage and exposure to agents that induce oxidative stress (Doğan et al., 2015; Bayne and Sohal, 2002). It is well established that natural antioxidants are usually harmless to human body. They are molecules that prevent early aging via blocking the catasthropic effects of the free radicals, many diseases and chain reactions (Elik et al., 2007).

Antioxidant enzyme activities are substantially enhanced by quercetin treatment (Elik et al., 2007). The study of Elik et al. (2007) proved that quercetin as a flavonoid with antioxidant characteristics demonstrates antidiabetic effects (Elik et al., 2007). This compound also has protection against oxidant damage to the heart, brain, liver, aorta and kidney for mid-term or long-term diabetic rat (Elik et al., 2007). Thus, quercetin increases the antioxidant defence capacity.

It has been shown that flavonoids could inhibit enzymes like cyclooxygenases and protein kinases where they are part of cell proliferation and apoptosis processes (Abdelmoaty et al., 2010). In addition, doses of 15-50 $\mathrm{mg} / \mathrm{kg}$ body mass quercetin was able to of normalize blood glucose level, augmenting liver glycogen ingredients and dramatically decreasing serum cholesterol and low density lipoprotein (LDL) levels in alloxandiabetic rats (Abdelmoaty et al., 2010). Furthermore, treatment of quercetin to isolated rat islets increased insulin production by $44-70 \%$ with changing in calcium flows and in cyclic nucleotide metabolism (Abdelmoaty et al., 2010).

Consumption of flavonoids showed a reduction in coronary heart disease (Hertog et al., 1994). The study conducted in Japan showed that there was a decreased on both total and LDL-cholesterol concentration when plasma quercetin is increased (Hertog et al., 1994). In another study in Finland showed that diet rich in apple and onion increased quercetin level which was helpful to reduce coronary mortality (Knekt et al., 1996).

Each alive organism is able to prevent negative effects of free radicals with antioxidative protection system. However, this system is not strong enough to prevent an increase in the amount of radical. Consequently, oxidative stress (cell damage) occurs in this situation. Low level of stress induces a cell to activate extra defence system, although, high-stress level causes the death of cells which damages organisms (Çı1krıkçı, 2005). All these studies are demonstrating that quercetin has an anti-oxidative effect to inhibit oxidative stress.

A series of epidemiological studies proved that a lack of association between flavonoids consumption up to 68 
mg total flavonoids/day (in large portion by high quercetin level) and incidence of all variety of cancer (Hertog et al., 1995; Lin et al., 2006). On the other hand, there are studies indicated a negative correlation between up to $40 \mathrm{mg} /$ day flavonoid consumption (95\% of it quercetin) and cancer incidence (Knekt et al., 1997; Knekt et al., 2002).

It is demonstrated that triptolide (TP)-induced oxidative stress and a decrease of testosterone generation could be prevented by quercetin (Hu et al., 2015). Different concentrations of TP were applied to Leydig cells to cause oxidative stress with high intracellular reactive oxygen species resulted in reduction activities and expressions of glutathione peroxidase and superoxide dismutase. Results of this study imply that quercetin could lower the TP-induced reproductive toxicity, which support the usage of TP.

The inhibition effect of quercetin against oxidative stress, which caused by sodium fluoride, was investigated in rat's liver (Nabavi et al., 2012). Five groups of rats were treated with different diets; the first group served standard diet, the second group was intoxicated with sodium fluoride $(600 \mathrm{ppm})$ via drinking water for a week. The third, fourth and fifth groups were applied with quercetin at a dose of 10 and $20 \mathrm{mg} / \mathrm{kg}$ and vitamin $\mathrm{C}$ (as the positive control) at a dose of $10 \mathrm{mg} / \mathrm{kg}$ intraperitoneally for 1 week ahead of sodium fluoride intoxication, seriatim. Activities of superoxide dismutase and catalase, the amount of decreased glutathione and lipid peroxidation end product were measured 1 week later treatments of rat liver. According to the data of this work that quercetin preserves rat liver from sodium fluoride activated oxidative stress, most likely by its antioxidant action (Nabavi et al, 2012). It is also demonstrated that quercetin prevents perfluorooctanoic acid-induced liver damage via mitigating oxidative stress and inflammatory response in mice (Zou et al., 2015). As pointed out, mitochondrial oxidative stress has a main role in the pathology of myocardial infarction (Czepas and Gwoździński, 2014). In this study, pretreatment of quercetin reduced the activities of serum creatine kinase, lactate dehydrogenase, heart mitochondrial lipid peroxidation products and dramatically enhanced the amounts of mitochondrial antioxidants. In addition, quercetin also cured the activities of tricarboxylic acid cycle and respiratory chain enzymes almost normal level in myocardial infarcted rats. The action of quercetin on cardiac mitochondrial oxidative stress could reduce mitochondrial lipid peroxidation; enhance levels of mitochondrial antioxidants and activities of mitochondrial marker enzymes. As a result, heart mitochondria of rat are protected to isoproterenol-stimulated oxidative stress in vivo in myocardial infarction (Czepas and Gwoździński, 2014).

Quercetin is the most abundant polyphenolic in human food and the absences of its toxicity-genotoxicity has been proved. It has high importance due to chemo preventive and anticancer values. In general, all these values might point out the possible treatment of quercetin as cardio protectant through anthracycline chemotherapy.
Moreover, all these favourable impacts to anthracyclineinduced complications of chemotherapy need to be more studied and validated both in animal and clinical works. The experiment was established to test the hepatoprotective effect of quercetin compared to $\mathrm{N}$ acetylcysteine (NAC) against hepatic I/R injury in rats and to determine iNOS, eNOS, and NOSTRIN protein expressions, as a possible mechanism of its hepatoprotective effect. As a result, quercetin application improved eNOS protein expression with a simultaneous decline in iNOS and NOSTRIN protein expressions. In addition, pretreatment of quercetin decreased serum aspartate aminotransferase, alanine aminotransferases and hepatic myeloperoxidase activities and recover the extinct content of decreased glutathione, malondialdehyde, and nitric oxide levels (Abd-Elbaset et al., 2015).

Neurodegenerative disorders are formed with complex processes, basically associated to advance brain injury capturing cellular death. Biochemical reactivity related to these processes in Alzheimer's disease contains, among others, metal-induced oxidative stress promoting to neuronal cell demise. One of the active redox metals causing oxidative stress is $\mathrm{Cu}$ (II) (Naday et al., 2015). Lately, the effort is to produce bioactive hybrid nanoparticles that have the capability to work as hostcarriers for potential antioxidants, for instance, the natural flavonoid quercetin. In molecular technology silica nanoparticles were assembled with synthetic protocols to produce PEGylated and CTAB-modified materials.

\section{Conclusion and Future Prospects}

The current review deals with the basic biological functions of quercetin, such as antioxidant, anticarcinogenic, anti-inflammatory, and cardio protective properties. Furthermore, prevention of tumour development and possibility of flavonoid-drug interaction have been also discussed. We shared these biological properties of quercetin with a common mechanism of antioxidant action in this review. Critical evaluation of biological effects of quercetin leads to raising a conclusion that at estimated dietary intake levels would not cause adverse health problems, even; daily consumption would be extremely beneficial for human daily activities.

\section{Competing Interest}

The authors declare that they have no conflict of interest.

\section{References}

Abd-Elbaset M, Arafa AE, El Sherbiny G, Abdel-Bakky M, Elgendy ANAM. 2015. Quercetin modulates iNOS, eNOS and NOSTRIN expressions and attenuates oxidative stress in warm hepatic ischemia-reperfusion injury in rats. Beni-Suef Univ. J Appl Sci. 4: 246-255.

Abdelmoaty MA, Ibrahim MA, Ahmed NS, Abdelaziz MA. 2010. Confirmatory studies on the antioxidant and antidiabetic effect of quercetin In Rats. Indian J Clin Biochem. 25:v188-92. 
Beecher GR. 1999. Antioxidant Food Supplements in Human Health, Flavonoids in Foods Boots AW, Kubben N, Haenen GRMM, Bast A. 2003. Oxidized quercetin reacts with thiols rather than with ascorbate: Implication for quercetin supplementation. Biochem Biophys Res Commun. 308:v560 565 .

Boots AW, Kubben N, Haenen GRMM, Bast A. 2003. Oxidized quercetin reacts with thiols rather than with ascorbate: Implication for quercetin supplementation. Biochem Biophys Res Commun. 308:v560-565.

Bors W, Heller W, Michel C, Saran M. 1990. Radical chemistry of flavonoid antioxidants. In: Emerit, I.; Packer, L.; Auclair, C. (Eds.) Antioxidants in Therapy and Preventive Medicine. Advances in Experimental Medicine and Biology. Plenum Press. 264 New York, p. 165-170.

Brown JE, Khodr H, Hider RC. 1998. Rice-Evans, CA. Structural dependence of flavonoid interactions with $\mathrm{Cu}^{+}$ions: implications for their antioxidant properties. Biochem $\mathrm{J}$. 330:v1173-1178.

Çıkrıkçı S. 2005. The Synthesis and Characterızatıon of 4'Dioctylamıno-3- Hydroxyflavone based Fluorescence Probes. MD Thesis, Istanbul Teknik Universitesi.

Cook NC Samman, S. Flavonoids. 1996. Chemistry, metabolism, cardioprotective effects, and dietary sources. J Nutr Bioche. 7:v66-76.

Czepas J, Gwoździński K. 2014. The flavonoid quercetin: possible solution for anthracycline-induced cardiotoxicity and multidrug resistance. Biomed Pharmacother. 68: 1149-59.

D'Andrea G. 2015. Quercetin: A flavonol with multifaceted therapeutic applications. Fitoterapia. 106: 256-271.

Das NP. 1989. Flavonoids in Biology and Medicine III, National University of Singapore, Singapore.

Doğan Z, Kocahan S, Erdemli E, Köse E, Yılmaz, Ekincioğlu Z, Ekinci N, Türköz Y. 2015. Effect of chemotherapy exposure prior to pregnancy on fetal brain tissue and the potential protective role of quercetin. Cytotechnology. 67: 1031-1038.

Elik M, Serdaroğlu G, Özkan R. 2007. The Investigation of Antioxidant Activities Of Myricetin And Quercetin With Dft Methods, C.Ü. Fen-Edebiyat Fakültesi Fen Bilimleri Dergisi. 28: 2 .

Ghosh N, Chakraborty T, Mallick S, Mana S, Singha D, Ghosh B, Roy S. 2015. Synthesis, characterization and study of antioxidant activity of quercetin-magnesium complex. Spectrochim Acta A Mol Biomol Spectrosc. 151: 807-813.

Gutteridge JM. 1995. Lipid peroxidation and antioxidants as biomarkers of tissue damage. Clin Chem. 41: 1819-1828.

Hertog MG, Feskens EJM, Hollman PCH, Katan MB, Kromhout D. 1994. Dietary flavonoids and cancer risk in the Zutphen elderly study. Nutr Cancer. 22: 175-184.

Hertog MGL, Kromhout D, Aravanis C, Blackburn H, Buzina R, Fidanza F, Giampaoli S, Jansen A, Menotti A, NedeljkovicS, Pekkarinen M, Simic BS, Toshima H, Feskens EJM, Hollman $\mathrm{PCH}$, Katan MB. 1995. Flavonoid intake and long-term risk of coronary heart disease and cancer in the seven countries study. Arch Int Med. 155: 381-386.

Hu J, Yu Q, Zhao F, Ji J, Jiang Z, Chen X, Gao P, Ren Y, Shao S, Zhang Z, Yan M. 2015. Protection of Quercetin against Triptolide-induced apoptosis by suppressing oxidative stress in rat Leydig cells. Chem Biol Interact. 240: 8-46.

Knekt P, Ja"rvinenR, Seppa"nenR, Helio“vaara M, Teppo L, Pukkala E, Aromaa A. 1997. Dietary intake of flavonoids and the risk of lung cancer and other malignant neoplasms. Am J Epidemiol. 146: 223-230.

Knekt P, Kumpulainen J, Jarvinen R, Rissanen H, Heliovaara M, Reunanen A, Hakulinen T, Aromaa A. 2002. Flavonoid intake and risk of chronic diseases. Am J Clin Nutr. 76 (3): 560-568.
Knekt PJ, Reunanen A, Maatela J. 1996. Flavonoid intake and coronary mortality in Finland: a cohort study. Br Med J. 312:478-481.

Lin J, Zhang SM, Wu K, Willett WC, Fuchs CS, Giovannucci E. 2006. Flavonoid intake and colorectal cancer risk in men and women. Am J Epidemiol. 164: 644-651.

Martins HF, Leal JP, Fernandez MT, Lopes VH, Cordeiro MN. 2004. Toward the prediction of the activity of antioxidants: experimental and theoretical study of the gas-phase acidities of flavonoids. J Am Soc Mass Spectrom. 15:848-861.

Metodiewa D, Jaiswal AK Cenas N, Dickancaite E, Segura- Aguilar J. 1999. Quercetin may act as a cytotoxic prooxidant after its metabolic activation to semiquinone and quinoidal product. Free Radic Biol Med. 26: 107-116.

Mitchell LJ. 1965. Spectrophotometry of Molybdenum, Tungsten and Chromium chelates of quercetin. PhD Thesis, Oregeon State University: USA.

Nabavi SD, Nabavi SF, Eslami S, Moghaddam AH. 2012. In vivo protective effects of quercetin against sodium fluoride-induced oxidative stress in the hepatic tissue. Food Chem. 132: 931-935.

Naday CM, Halevas E, Jackson GE, Salifoglou A. 2015. Quercetin encapsulation in modified silica nanoparticles: potential use against $\mathrm{Cu}$ (II)-induced oxidative stress in neurodegeneration. $\mathrm{J}$ Inorg Biochem. 145: 51-64.

Preedy V, Sung MT, Chen YC, Chi CW. 2014. Quercetin's Potential to Prevent and Inhibit Oxidative Stress-Induced Liver Cancer: London. p 231-239.

Rahman A, Fazal F, Greensill J, Ainley K, Parish JH, Hadi SM. 1992. Strand scission in DNA induced by dietary flavonoids: role of $\mathrm{Cu}(\mathrm{I})$ and oxygen free radicals and biological consequences of scission. Mol Cell Biochem. 111(1-2): 3-9.

Rice-Evans CA, Miller NJ, Paganga G. 1996. Structure-antioxidant activity relationships of flavonoids and phenolic acids. Free Radic Biol Med. 20: 933-956.

Rietjens IM, Boersma MG, van der Woude H, Jeurissen SM, Schutte ME, Alink GM. 2005. Flavonoids and alkenylbenzenes: Mechanisms of mutagenic action and carcinogenic risk. Mutat Res. 574: 124-138.

Sahu SC, Washington MC. 1991. Quercetin-induced lipid peroxidation and DNA damage in isolated rat-liver nuclei. Cancer Lett. 5 (1\&2): 75-79.

Selamoglu Z, Ustuntas HE, Ozgen S. 2016. Traditional and complementary alternative medicine practices of some aromatic plants in the human health. Research Journal of Biology. 4 (2): $52-54$.

Silva MM, Santos MR, Caroco G, Rocha R, Justino G, Mira L. 2002. Structure-antioxidant activity relationships of flavonoids: A reexamination. Free Radic Res. 36: 1219-1227.

Vasilescu D, Girma R. 2002. Quantum molecular modeling of quercetin-Simulation of the interaction with the free radical tBuOO. Int J Quantum Chem. 90: 888-902.

Wang L, Tu YC, Lian TW, Hung JT, Yen JH, Wu MJ. 2006. Distinctive antioxidant and antiinflammatory effects of flavonols. J Agric Food Chem. 54: 9798-9804.

Yáñez J, VicenteV, Alcaraz M, Castillo J, Benavente-Garcia O, Canteras M, Teruel JA. 2004. Cytotoxicity and antiproliferative activities of several phenolic compounds against three melanocytes cell lines: relationship between structure and activity. Nutr Cancer. 49: 191-199.

Zou W, Liu W, Yang B, Wu L, Yang J, Zou T, Liu F, Xia L, Zhang D. 2015. Quercetin protects against perfluorooctanoic acidinduced liver injury by attenuating oxidative stress and inflammatory response in mice. Int Immunopharmacol. 28: $129-135$. 